\title{
Creating Brand Equity by Leveraging Value Creation and Consumer Commitment in Online Brand Communities: A Conceptual Framework
}

\author{
Jing Zhang ${ }^{1}$, Rizwan Shabbir ${ }^{1}$, Chatchai Pitsaphol ${ }^{1}$ \& Waseem Hassan ${ }^{2}$ \\ ${ }^{1}$ School of Management, Huazhong University of Science and Technology, Wuhan, P.R. China \\ ${ }^{2}$ School of Economics and Management, China University of Geosciences, Wuhan, P. R. China \\ Correspondence: Rizwan Shabbir, School of Management, Huazhong University of Science and Technology, \\ Wuhan, 430074, P. R. China. E-mail: rizwanshabbir@hust.edu.cn
}

Received: November 7, 2014

Accepted: December 2, 2014

Online Published: December 20, 2014

doi:10.5539/ijbm.v10n1p80

URL: http://dx.doi.org/10.5539/ijbm.v10n1p80

\begin{abstract}
Advancement in information technologies has created change in our economics as well as in our societies because companies strive to adapt the conditions that prevail in marketplace. In this scenario, marketing professionals are exploring advanced and effective ways to build a strong brand. The research objectives explore the impact of online brand communities on brand equity dimensions through which consumer could achieve commitment and value-creation. While, marketing managers could explore attributes regarding brand perception, information and resource sharing and brand loyalty. A framework is proposed based on the drivers of online brand community and its influence on the dimensions of brand equity. From theoretical perspective, this study contributes to branding literature by exploring strategies for value-creation, brand image and integrated marketing communication. Additionally from marketing perspective, the drivers will guide managers to understand the want and desire of target audience. The building of such online brand communities will raise the return of investment, save marketing cost, enhance consumer loyalty, improving product development and providing circumstances for co-creation. Thus, it will provide ever-lasting consumer-brand relationship and substantial information about consumer behavior.
\end{abstract}

Keywords: brand equity, consumer commitment, online brand community, value-creation

\section{Introduction}

Brand management through the lens of brand-community relationship continues to be common in recent years. The consumer perspective towards brand can be explained as a promise which creates satisfaction through combination of different attributes resulted in a purchase of a product/service (Ambler, 1992). Therefore, it is defined as the process which creates a unique name and perception for a product/service in customer mind by using persistent promotional or marketing activities which develop recognition that differentiate the product/service from competing brand with an aim to attract and engage loyal consumers. The prior branding literature has indicated that state of resonance identifies the highest degree of association between brand and customer (Keller, 2003). In this degree of association consumers is highly loyal and they care about the brand success by connecting themselves with other consumers of same brand. Additionally as consumer care about the brand, it influences the consumer participation and experience that result in increasing recommendations, emotional attachment and relationship building (Ouwersloot, \& Odekerken-Schröder, 2008).

Meanwhile, emerging consumption culture has substituted mass production with differentiated goods that are identified with brand names and mass promotions by individual promotion (Muñiz \& O'Guinn, 2001). As, brands are spending their valuable resources to capture market share and win consumer trust, this resulted in intense competition and higher marketing cost which affect the prices and target customers (Casalo et al., 2008). To solve such problem, managers need to engage consumer in eternal relationship with brand and other members. Therefore, customer relationship management is considered as prevailing marketing strategy that could solve customer retention and interaction (Morgan \& Hunt, 1994; Andersen, 2005). For that reason, interest in this study is originated from the work of Porter et al. (2011) which proposed that to encourage consum with respect to brand-customer relationship should require learning about consumer need and wants. Nowadays, consumer 
decisions are more obsessed with the information provided on internet because people belief the experience of others as product feedback or advice (Kozinets, 2002).

The information and communication Technologies have brought a new pattern for marketing activities which came along with social links and product/service affiliations. These communication activities are vital source for the pursuit of customer relationship management (Andersen, 2005). Many academic scholars and marketing managers are exploring this new field of brand management. Meanwhile, famous brands have created their online brand communities which engage consumer at global level. These communities affect the societal identities and consumer-brand relationship. At first, activities and participation of these brand communities appear as physical and limited to a specific region but social media has changed the paradigm of participation and engagement in a brand community from regional-level to global-level (Wirtz et al., 2013). The dynamics and outcome of online brand community traits have been studied in some extent but examination of consumer behavioral aspects are still missing in analyzing consumer-brand relationship. These behavioral aspects could be valuable for evaluating brand perception and recognition by means of information sources.

The purpose of this study is threefold: firstly, it recognizes those brand equity dimensions that should improve consumer commitment and attachment. Secondly, it explores the online brand communities' traits which involve learning consumer value proposition and identifying beneficial indicators to attract and engage consumers. Lastly, it investigates competitive behavior and consequences of consumer evaluation through disseminating opinions. We structure this paper by explaining online brand community characteristics and its role in brand management then providing theoretical relationship between drivers of online brand community and brand equity dimensions. After that, we explain a framework with proposed practical and managerial implications.

\section{Characteristics of Online Brand Community (OBC)}

In marketing literature, the concept of brand communities was initialized from the work of Muniz and O'Guinn (2001) which construe brand community as "a specialized, non-geographically bound community, based on a structured set of social relationships among admirers of a brand" (p. 412). The description of brand community in marketing was taken from sociological perspective in which the composition of a community is blend of mutual social relations and social bonds (Bender, 1978). It is a consumer-centric process; in which the vital factor is consumer participation which considers active engagement of members in brand community activities. The three basic aspects of brand communities were identified by Muniz and O'Guin (2001) which includes shared consciousness, rituals and traditions and sense of moral responsibility. Afterwards, lot of marketing scholars have identified various ways to analyze the process of online brand communities advancement such as McAlexander et al., (2002) examined the relationship between consumer participation and brand loyalty, Bagozzi and Dholakia (2006) investigated consumer participation in OBCs, and Tsai et al., (2012) explored the OBCs effects on brand equity through exchange process. The contribution of community participation provides brand manager with relevant information about many product attributes that will guide in product development and improvement (Algesheimer et al., 2005). The long-term success of brand community depends on the participation of existing members and components of community that engage new members.

Prior research on brand communities has contributed to the development of consumer knowledge by offline and online brand communities. Matzler et al. (2011) concluded three important factors of brand communities that can be used by marketing managers for strengthening the consumer-brand relationship. Firstly, it is a source of market information (Füller et al., 2008). The information about customers presented desires of target audience and detailed knowledge about product and its usage. Secondly, such brand communities provide a specific market segment contains highly devoted consumers with special marketing desires (Bagozzi \& Dholakia, 2002). The highly devoted consumers are best source for product development, co-creation and grassroots marketing campaigns. Thirdly, brand communities are vital for promoting consumer-brand and consumer-consumer relationship because participating in a community creates connection that leads to brand advocates (Algesheimer et al., 2005; Andersen, 2005; Bagozzi \& Dholakia, 2006). The brand advocates are consumers that defend the brand and its marketing strategies towards targeted customers.

From the lens of brand communities, there are three fundamental relationships that impact consumer behavior: consumer-brand, consumer-consumer and consumer-community relationship (Muniz \& O'Guinn, 2001). For this study, we focused on all these three relationships: consumer-brand relationship provide us drivers for online brand community participation, consumer-consumer relationship provide the reasons of consumer interaction and participation by supporting one another and consumer-community relationship provide the factors of value creation and commitment. In general, people think online brand communities as consumer bonds but it is far beyond that. By using online brand communities consumer participate in consumption related tasks that serve as 
a platform for sharing their information with other members and increasing their expertise in using that product/service (Bagozzi \& Dholakia, 2002). An online brand community grows brand loyalty and attachment by supporting members in better utilization of products and its usage.

Previously, the idea of brand communities was to ease the linkage between brand and loyal consumers but with the introduction of social media such communities become globalized and they serve as a medium of marketing communication and consumer engagement. Nowadays, information and communications technologies supported brands to go beyond the horizon of geographical proximity that demanded marketing managers to develop such strategies that can be implemented in a globalized pattern. The online brand community is just one example of such communication channel which allows engagement and participation among members. The online communities construct a bond among members that become their identification for information exchange related to product/service, lead towards community commitment and long-lasting affiliations (Kim et al., 2008).

From company perspective, online brand communities assist companies to capture customer attention by providing platform for sharing knowledge and building relationship (Stokburger-Sauer, 2010). Many international brands have created their official communities that are managed by managers through which they analyze different brand equity dimensions. Fournier et al. (2005) conducted a study in which they described that companies establish their brand communities for building long-term relationship with devoted consumers so that they can create and maintain competitive advantage. With respect to relationship marketing, the key dimension is the communication with target audience. The communication can occur through different sources but involving audience in a marketing campaign is essential for producing more brand involvement and customer loyalty (Bagozzi \& Dholakia, 2002). Such relationship techniques are used for brand building and establishing consumer base but the advancement in information and communication technologies changed the paradigm of audience involvement beyond creating loyal customers.

Mostly, online brand communities are created for consumption-related products/services which include leisure, hedonic, cosmetics and technology. These products/services are valuable source for extracting marketing information for future research and development (Kozinets, 2002; Bickart \& Shindler, 2001). Moreover, marketing managers can generate precise, more detailed, customized and multidimensional facts about targeted consumer at a very low cost as compared to other marketing research tools (Kozinets, 1999). As consumer are more accessible through social media, so marketing strategies could more concentrate on strengthen the relationship among consumer-brand. On the contrary, Bagozzi \& Dholakia (2002) suggested that members of online brand community can be perceived as a market segment with enthusiast consumers based on their passion and attachment. If we consider them as a separate segment characterized by demographic and attachment, managers could specify suitable and productive marketing communications. This market segment could also be spread positive and effective word of mouth that will create competitive advantage and stronger long-term relationship (Kozinets, 1999). Lastly, online brand communities are vital for increasing loyalty among consumer that generate sales, consumption and engagement of consumer in that product/service (Armstrong \& Hagel, 1996). As loyal consumers connect with brand and other members on online communities, they provide ideas to better development and expand the brand image and awareness in the society. Such developments in consumer culture enforce organizations to build their brand communities and approx 50\% of top global brands has established their brand communities till 2012 (Manchanda et al., 2012).

\section{Theoretical Background}

Based on previous literature and discussion on different forums, we summarize the major contribution of authors towards online brand communities literature and practical implications. Yet, the inadequacy of literature regarding preconception of online brand communities and its impact on consumer based brand equity that contribute to building relationship orientation with consumers is a missing link for managers. However, consumer perspective on brand equity contains prominent significance for every organization because it comprises on fundamental dimensions that consumer evaluate for a product/service.

At first, product/service produced by an organization with a brand name might be synonymous for consumers but different marketing activities such as advertising and usage experience generate brand associations that prevail with the passage of time and build brand attachment. The dimensions of brand equity gain their importance when consumers thought brands as indispensable factor and considered it more that a product/service. This creates variation in consumer preferences that effect brand awareness, image and value (Alagoz et al., 2011). The consumer's desire is to get maximum value from the product and brand because positive experiences about the brand enhance interaction and involvement which fabricate customer-brand relationship (Algesheimer et al., 2010). The study of Thompson \& Sinha (2008) suggested that when a consumer develops affiliation with a brand 
community, he/she has tendency to actively participate and adopt new products or services offered by that company as compared to competing brands. There are various forms of consumer engagement in an online brand community which includes active participation, providing recommendations, spreading word of mouth and gathering information about product could be summarized as brand loyalty (Algesheimer et al., 2005). Based on these brand equity dimensions, we extract major drivers that influence consumer to participate in an online brand community.

\subsection{Drivers of Online Brand Communities (OBC)}

To fabricate a successful consumer-brand relationship, $\mathrm{OBC}$ provide benefits to the members that act as driver to participate and engage interaction in that brand community. Previous studies identified different motives to participate in an OBC, such as Dholakia et al. (2004) concluded five value perceptions which are purposive, self-discovery, maintaining interpersonal interconnectivity, social enhancement and entertainment value. These motivates engage consumer in an $\mathrm{OBC}$ through media. With respect to level of participation, Wang \& Fesenmaier (2004) conducted a study which determines four groups of drivers as functional, psychological, social and hedonic drivers. A study conducted by Sicilia \& Palazon (2008) explore that members contribute in an OBC based on functional, social and entertainment values. Yen, Hsu, and Huang (2011) suggested three categories of drivers for member's participation in an OBC which are self-enhancement (includes improvement in reputation and rank), rewards (includes instrumental values) and problem solving support (it includes assisting other members in customizing, using or trouble shooting).

Based on previous literature, we group the $\mathrm{OBC}$ traits into four categories based on virtual interactions and brand community motives which includes learning, social, self-esteem and hedonic. The learning driver includes information and knowledge about the product of a brand. When consumer join the $\mathrm{OBC}$, he/she can gain or share communication among members about specific product or brand. The learning drivers refers to informational benefits which help consumer to gather and collect information about the product/brand and instrumental benefits consists on guiding and solving problems regarding product use (Nambisan \& Baron, 2009; Yen et al., 2011). Social driver includes benefits that strengthen the member's participation through its knowledge about the product such as friendship, social enhancement and emotional support. The self-esteem drivers are related to reputation and status that an individual seek in an OBC. The members of an OBC could gain respect and rank by guiding other members or helping new comers in making decisions about product usage (Dholakia et al., 2004; Sicilia \& Palazon, 2008). Lastly, the hedonic drivers are related to entertainment that consumer find through joining the brand community or numerous pleasure that consumer seek in OBC. The hedonic drivers motive consumers to participate more and allocate their leisure time in OBC activities (Wang \& Fesenmaier, 2004). These drivers influence the consequences of $\mathrm{OBC}$ such as value creation and consumer commitment.

\subsection{Online Brand Communities Activities}

\subsubsection{Value Creation}

The study of Schau et al. (2009) revealing four types of practices by means of which consumer can fabricate value in an brand community which includes social networking, impression management, community engagement and brand use. Pervious literatures showed that consumers are not only receiving benefits to the firm and the product but also guide in co-productive activities for competitive advantage, factors of engaging consumer, product/process innovation and value creation (ibid).

Based on the work of Schau et al. (2009), we define social networking practices as an attempt to create, enhance and sustain the relationship between the brand community members. These practices emphasize on the similarities and behavior among brand community members. Social networking practices are grouped as welcoming, empathizing and governing. The welcoming practice includes appreciating new members, helping them in learning about brand and building connection with other members. Empathizing practice consist on providing emotional or physical favor to other member and building brand value through WOM marketing or taking part in brand related trials. Governing practice consist on norms of the brand community or behavioral belief of community members. Social networking practices are also confirmed from the literature of Muniz and O'Guinn (2001) which explain the shared consciousness and emotional bong among brand community members.

Usually, community engagement is an attribute through which community provide benefit to the firm and its members by strengthen the relationship between them. With respect to value creation, community engagement practices are mentioned as those practices which boost the members association with brand community (Schau et al., 2009). These practices consist on staking, mile-stoning, badging and documenting influential events such as personal experiences. Community engagement emphasize on creating cohesive behavior in brand community (ibid). It is an activity which gathers all the members of community for a common objective and builds social 
capital for community members. Staking involves identifying variation in brand community memberships because different sub-community are created based on common interests. Mile-stoning practice contains events that generate while consuming or attending different ceremonies of brand. Furthermore, badging practice refer to converting milestone events into different badge for strengthen the brand relationship. Documentation practice includes narrating different events, sharing personal experiences with other members and fabricating special brand moments.

In general, it is purposive behavior through which people try to impact the perception of people in a group about an event or thing. In brand communities, impression management is defined as "activities that have an external, outward focus on creating favorable impressions of the brand, brand enthusiasts and brand community in the social university beyond the brand community" (Schau et al., 2009, p. 34). Thus, impression management practices are grouped as evangelizing practices and justifying practices. The evangelizing practice includes sharing inspiring stories about brand, comparing with other brands and increasing the goodwill. Furthermore, justifying practice includes the attempt to solve problems of new members and outsiders and allocating time for creating activities related to brand promotion. Different impression practices are apparent in previous research literature such as (Kozinets et al., 2001 \& Muniz and Schau's 2005) conclude that consumers are involved activities for attaining higher position in brand community. Similarly, OBC promotes brand name through WOM communication and telling personal perception about brand. By using these practices community members spread the brand beliefs, participate in promoting news about brand and encourage other people to use it. Contrary, these practices are very complex because they are interconnected with brand use and community engagement practices (Kozinets et al., 2010). We consider that these practices are also apparent in OBC and enhance the effectiveness of brand equity.

Brand use practices are concluded by Schau et al. (2009) as the activities that resulted in enhancing and promoting techniques to use of focal brand. It includes practices like grooming, customizing and commoditizing. Brand practices consist on the information shared by one community member to another. In grooming practices, members share attributes regarding caring or optimal use of brand and prepare new community members for active participate in community events. Customizing practice includes brand reshaping based on community or individual needs and modifying the product/service to increase performance and efficiency. Such activities create attraction for brand users to join and participate. Commoditizing practice describe behavior of community members about marketplace. As whole, brand use practices tend to build member's attitude towards refined and enhanced technique to use the product/brand. In this manner, the information generated by a consumer about a product benefit other consumer in customizing according to their needs/wants. Laroche et al., (2012) concluded that such brand practices are also linked with the emotional aspect of members which build bonding between consumers by information sharing.

\subsubsection{Consumer Commitment}

To flourish stronger consumer brand relationship commitment towards product/service creates a bond among consumer and their respective communities (Morgan \& Hunt 1994). The commitment provides consumer with benefits, involvement and participation in community activities. Moorman et al. (1992) described consumer commitment as "the enduring desire to maintain a valued relationship". It also indicates an engagement process by which loyal consumers interact with community members. Such affective commitment encourages co-creation and brand trust in a consumer. On the contrary, brand commitment is defined as emotional attachment with the brand because commitment leads for enthusiasm (Fournier, 1998). In the circumstances of online communication, information posted by members and consumer commitment towards its response are prerequisite factors for engaging consumers and improving marketing performance (Ridings et al., 2002). In an $\mathrm{OBC}$, both emotional attachment and relationship is necessary to produce the elements to make an online brand community successful because Kim et al. (2008) suggested that consumer attitude is based on brand trust and recognition. Prior researches have concluded that $\mathrm{OBC}$ participation shown a positive and significant impact on community commitment (Casal'o et al., 2008).

\subsection{Online Brand Communities Outcomes}

\subsubsection{Consumer Based Brand Equity (CBBE)}

The objective to every organization is to initiate a strong brand that produce significant equity by offering benefits to consumers (Keller, 2001). The perceived benefits raise brand value, loyalty and brand performance. The model of CBBE suggested that consumer hold a dominant power based on what he/she has perceived and heard regarding that brand over period of time (ibid). The consumers are connected to brand by their beliefs, perception and opinion about that product/service. Thus, $\mathrm{OBC}$ are considered as a tool for enhancing brand 
equity dimensions which resulted due to engagement and participation.

\subsubsection{Brand Perception}

Brand association relates the brand in consciousness of consumer that develop a positive attitude towards the product which is attached with that brand. Brand association has been identified into three groups as: functional, performance-related and imagery-related (Keller, 2001). These brand associations in consumer are created from experience and information collected about product/brand from different sources. Brand performance describes those techniques which seek to meet consumer functional needs and explained as intrinsic properties of a brand/product. Brand perception relies upon the performance of the product which is measured through its reliability and durability. The familiarity with consumer preferences is perceived as an essential success factor for the product (Cooper \& Kleinschmidt, 1996).

Brand image is an outcome of perceptions and association that a product/brand leave in consumer's mind because it involves all the beliefs that create value and consumer commitment (Alagoz et al., 2011). Nowadays, consumer evaluates product/service based on their brand image rather than the product itself. Alagoz et al. (2011) concluded in their study that brand image is the association of the product/service in consumer's mind which tends to become a purchasing activity and overall creates brand loyalty. The consumer needs and wants provide information about the desired product/service that information act as brand perception which serves as competitive advantage. Marketing managers design their strategies based on brand perception but obtaining such precise information is a key challenge because after every purchase consumer experience and brand association has shown variation (Lipinski et al., 2011). The basic purpose of social communities is to share information among the members, thus organizations use brand communities for collecting valuable insights about desired product/service. Through brand communities, organization also promotes their product/services and collects information regarding product performance and associations. Moreover, evangelists provide critical feedback to the managers that lead to product development and strengthen consumer-brand relationship. Thus, online brand communities could provide actual information about brand perception that should evolved as a competitive advantage for the organization.

Previous studies about online shopping behavior concluded that higher consumer satisfaction and involvement resulted in higher probability to promote brand image $(\mathrm{Li}, 2011)$ because when consumer involved in a purchase process by collection information, experience about the product/brand, this cause effects on satisfaction and brand perception.

\subsubsection{Brand Loyalty}

Brand resonance is described as the depth of the emotional bond between consumer and brand which result actions that arouse from this loyalty (Keller, 2001). The brand relationship is divided into two groups based on intensity and activity. The intensity relationship mentions attitudinal attachment of the consumer and becoming a part of the brand community. The activity relationship describes behavioral loyalty and consumer engagement in brand activities. Due to the advancement in technologies, marketplace becomes a complicated place for organization to compete and communicate with target consumer. As communication medium evolve, it create more complex circumstances for marketing managers to convey their message. Modern technologies influence the behavioral attributes of consumers that shift the desire of a product/service; to fulfill that demand managers require feedback which becomes complex due to the subdivision in the demographic groups.

At present, communication is a two-way process in which consumer acquire more power due to online platforms that provides various means to participate and join marketing activities related to that brand/product (Lipinski et al., 2011). In an online brand community, the important issue is the strength of the relationship between consumer and brand. Thus, organizations thrive to develop a strong bond with consumer by providing various opportunities and platform to participate and engage in brand activities which result in evangelist consumers.

\subsubsection{IMC and Relationship Satisfaction}

The transformation in information technology has changed the pattern of marketing segmentation and it prepares marketing managers to adopt new marketing communication instruments that engage and facilitate individual consumer (Kotler \& Armstrong, 2005). The objective of IMC is to strengthen the effectiveness of marketing communication for target consumers through managing different communication mediums instead of managing every component of marketing management (Yoo, 2009). Meanwhile, the marketing cost incurred by organization call upon those marketing activities that should develop sustainable ever-lasting relationship by using minimal resources (Reid, 2005). The practical implementations of IMC inside the boundaries of OBC provide opportunities for managers to create marketing communication mix which enhance participation and 
engagement of members while providing insight information regarding consumer desires.

As, advanced technologies have brought new communication mediums which accredit marketing managers to contact with target consumers by using precise message. With adoption of such technologies, loyal consumers are shifting from traditional channels to more advancement channels that present them a platform to exchange reliable information about preferred brand/product. This process permits managers to collect reliable information through devoted consumers without any extra effort. The IMC context suggests that marketing activities could develop brand image and loyalty by engaging consumer actions with different promotional communications activities. Tremendous advancement in ICT's has facilitated marketing managers to collect more comprehensive information about consumer as collected before through online brand communities. Integrated information exchange in online brand communities could facilitate managers with consumer insights that might be integrated with brand perception for analyzing new product success and lower the marketing cost related to that.

The online brand communities depict the link of self presentation and relationship satisfaction of a brand because satisfaction is an affective state that produces an outcome of all the dimensions that formulate a relationship (Casalo et al., 2007). Particularly, we focused on affective perspective of relationship satisfaction because with every new interaction at $\mathrm{OBC}$, consumer's perception is nourished by new information which analyzes the level of satisfaction. With respect to digital media, the research has transformed from "consumer-brand" to "consumer-brand-consumer" which specify that consumption practices provide medium of interaction that increase relationship satisfaction and engage consumer in building brand equity through different means (Schembri, 2008, p. 9). The relationship generated through OBC among consumers or consumer-brand provides a platform to encourage participation and exchange to personal information which led to satisfaction and trust among community members (Spaulding, 2010). Such personal information built a relationship satisfaction that engage consumers in different IMC activities. The interactions at OBC's derive consumer perception with relation to the benefits he/she want to gain and impact their future participation. Therefore, it is imperative to incorporate IMC and relationship satisfaction as the outcome of online brand community activities.

\section{Proposed Framework}

We proposed that relationship marketing is important for OBC but managing such communities in an online environment is itself a challenge which requires tailor-made strategies at individual level which suits the brand image (Kapferer, 1997, p. 94). For that reason, consumer information regarding brand perception will be filtered for developing suitable integrated marketing communication which should derive brand loyalty and relationship satisfaction.

There are various theories through which effects of brand communities are studied and explored such as social capital theory (Coleman, 1988), social identity theory (Tajfel \& Turner, 1985) and (PSOC) Psychological sense of community (Woisetschläger et al., 2008). Based on our theoretical approach, we will apply psychological sense of community (PSOC) because it analyzes the individual aspects of information exchange among community members with behavioral attributes. Moreover, online brand communities are best suitable option to consumer to engage and build their social relationship and maximize their social capital based on new technologies.

Firstly, drivers of online brand communities obtained from consumer brand relationship provide motivations of consumer's participation in an OBC. This relationship is moderated by consumer expertise because if an individual is more expert in using online platform, the chance of participation increases. Secondly, the ties between consumer-community relationships investigate the effect of $\mathrm{OBC}$ participation on value-creation and consumer commitment. These $\mathrm{OBC}$ activities provide insights about $\mathrm{CBBE}$ in an $\mathrm{OBC}$. In order to explore CBBE from its constructs, the framework explores brand perception, brand loyalty and relationship satisfaction in $\mathrm{OBC}$ environment. These $\mathrm{CBBE}$ constructs impact the $\mathrm{OBC}$ activates and consumer decision to participate in an $\mathrm{OBC}$. With this intention, we probe dominant drivers of $\mathrm{OBC}$ traits and their consequences which influence brand equity and consumer behavior around which the online brand community is developed as shown in Figure 1. 


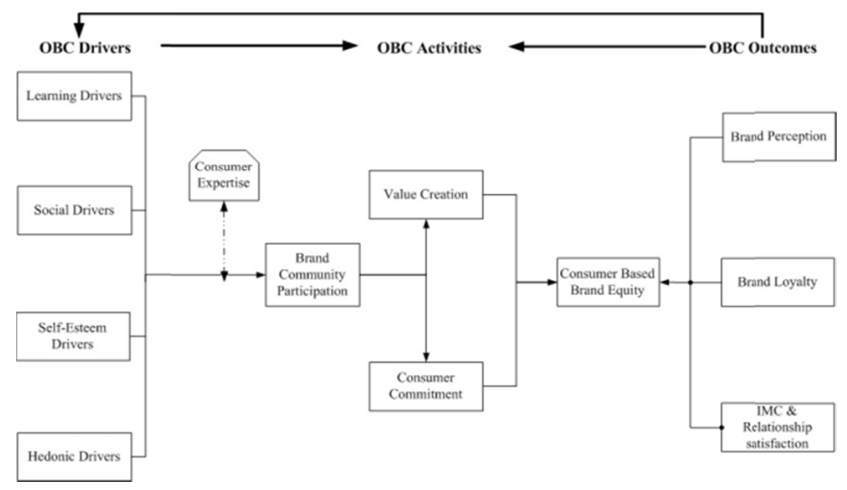

Figure 1. Conceptual model of drivers and outcomes of OBC

These everlasting consumer relationships provide managers with competitive advantage and originate value creation, commitment and enhance marketing performance and productivity. The consequence of online brand communities could lower marketing costs by switching the burden towards consumer relationship management and integrated marketing communication activities. Through this conceptual model, we can explore features that could lead to strong brand perception and improve brand values. As whole, we can summarize the drivers of online brand communities that influence consumer based brand equity and transform the paradox of consumer behavior.

The consumer expertise acts as moderator which affect the value creation and consumer commitment towards an OBC. It refers to the degree to which a consumer perceives himself/herself to be capable, knowledgeable, qualified and experienced about the product/service (Adjei et al., 2010). Prior studies on OBC suggested that when members exchange information, it lower the doubt about the product/service, despite when they perceive themselves as expert and knowledgeable about the product/service (ibid). It is certain that duration of membership has relationship with the adoption of new product/services because those members who are newcomer have fewer tendencies to adopt new products as compared with long-term members. The research of Thompson \& Sinha (2008) concluded that long-term members of a brand community are not expected to participate in activities related to competing brands specially, in adopting a new product/service. Moreover, McAlexander et al. (2002) suggested that managers could foster their brand communities by promoting engagement and participation through different marketing communication campaigns. Thus, consumer knowledge about a product/service enhanced the participation in an $\mathrm{OBC}$ due to the exchange of information, he/she acquire more value in a specific group with resulted in expert opinions and active engagement.

As we know that famous brand have captured market through different prevailing marketing activities and they have strong loyal customers base. This framework will work as a key for emerging brands to converge their abilities to engage promising consumers based on OBC. These strategic issues could guide academic scholars and practitioners to resolve the challenges in engaging consumers and governing OBCs. From technology perspective, this study investigates the consumer-consumer relationship based on new technologies, consumer expertise and knowledge that enhance the relationship satisfaction and consumer bonding.

\section{Conclusion}

Based on consumption behavior, branding is a vital aspect of a product/service because it demonstrate various attributes of consumer identity and brought integration among the likeminded consumers in society. It also mention heterogeneity of consumer relationship based on perceived benefits from a product/service. We expected that $\mathrm{OBC}$ traits could provide factor for enhancing value creation and commitment in online brand communities. By means of such enrichment in value creation and commitment, it likely to impact brand image, loyalty and power to affect consumer based brand equity.

The drivers of $\mathrm{OBC}$ could foster the participation of consumer in a brand community, thus identification of attributes about engagement and consumer brand relationship should develop a mechanism that create an environment which perceive precise capability to determine brand equity dimensions. The information exchange and resource sharing could provide platform for members to guide and assist other members regarding product and its usage. Moreover, it could provide opportunity for managers to promote their marketing activities without incurring any cost and involving devoted consumers. The marketing manager could use this framework for increasing $\mathrm{OBC}$ participation and consumer commitment. The drivers of $\mathrm{OBC}$ participation could be beneficial 
to targeting audience based on which $\mathrm{OBC}$ driver motivates them to engage in brand activities.

With regards to communication channels, OBCs could provide consumer insights to managers about the product/service which guide integrated marketing communication to tailor messages for consumer based on their interest and participation. The benefit of this study will raise the return of investment, save marketing cost, enhance consumer loyalty, improving product development and provide circumstances for co-creation. For long-term survival of brand, managers should develop such foundations that foster relationship, commitment and participation in marketing activities. As, traditional CBBE models consider brand perception and brand loyalty in an offline consumer interaction. Future studies should explore the impact of CBBE constructs on drivers of online brand community participation, which could provide a new domain for researcher. To do so, OBCs are important tool to accomplish these tasks with respect to brand equity dimensions. The relationship satisfaction of an online brand community has influence on the consumer's intention to continue its relationship by re-purchasing, recommendations and posting positive things about the brand or the product. Therefore, this study will strengthen the consumer brand relationship and provide valuable information about consumer behavior.

\section{Acknowledgement}

This research is sponsored by the "National Natural Science Foundation of China under Grant 71272125 " and "Fundamental Scientific and Research Program of Chinese Central Universities under Grant 2014QN207".

\section{References}

Adjei, M. T., Noble, S. M., \& Noble, C. H. (2010). The influence of C2C communications in online brand communities on customer purchase behavior. Journal of the Academy of Marketing Science, 38(5), 634-653. http://dx.doi.org/10.1007/s11747-009-0178-5

Alagoz, S. B., EkicI, N., \& Islek, M. S. (2011). Brand Communities in the Axis of Socializing Customers: Sample of Volkswagen Beetle Owners. Turkey. Ege Academic Review, 11(3), 465-477.

Algesheimer, R., Borle, S., Dholakia, U. M., \& Singh, S. S. (2010). The impact of customer community participation on customer behaviors: An empirical investigation. Marketing Science, (4), 756-769. http://dx.doi.org/10.1287/mksc.1090.0555

Algesheimer, R., Dholakia, U., \& Herrmann, A. (2005). The social influence of brand community: evidence from European car clubs. Journal of Marketing, 69(3), 19-34. http://dx.doi.org/10.1509/jmkg.69.3.19.66363

Ambler, T. (1992). Need-to-Know-Marketing. Century Business, London

Andersen, P. H. (2005). Relationship marketing and brand involvement of professionals through web-enhanced brand communities: the case of Coloplast. Industrial Marketing Management, 34(1), 39-51. http://dx.doi.org/10.1016/j.indmarman.2004.07.002

Anderson, J. C., \& Narus, J. A. (1990). A model of distribution firm and manufacturer firm working partnerships, Journal of Marketing, 54(1), 42-58. http://dx.doi.org/10.2307/1252172

Armstrong, A., \& Hagel, J. (1996). The Real Value of On-line Communities. Harvard Business Review, $134-141$.

Bagozzi, R. P., \& Dholakia, U. M. (2002). Intentional social action in virtual communities. Journal of Interactive Marketing, 16(2), 2-21. http://dx.doi.org/10.1002/dir.10006

Bagozzi, R. P., \& Dholakia, U. M. (2006a). Antecedents and purchase consequences of customer participation in small group brand communities. International Journal of Research in Marketing, 23(1), 45-61. http://dx.doi.org/10.1016/j.ijresmar.2006.01.005

Bagozzi, R. P., \& Dholakia, U. M. (2006b). Open source software communities: a study of participation in Linux user groups. Management Science, 52(7), 1099-1115. http://dx.doi.org/10.1287/mnsc.1060.0545

Bender, B. (1978). Gatherer-Hunter to farmer: A social perspective. World Archaeology, 10(2), 204-222. http://dx.doi.org/10.1080/00438243.1978.9979731

Bickart, B., \& Shindler, R. M. (2001). Internet Forums as Influential Sources of Consumer Information, Journal of Interactive Marketing, 15(2), 31-40. http://dx.doi.org/10.1002/dir.1014.abs

Casaló, L. V., Flavián, C., \& Guinalíu, M. (2008). Promoting consumer's participation in virtual brand communities: A new paradigm in branding strategy. Journal of Marketing Communications, 14(1), 19-36. http://dx.doi.org/10.1080/13527260701535236

Coleman, J. S. (1988). Social capital in the creation of human capital. American Journal of Sociology, 94, 
95-120. http://dx.doi.org/10.1086/228943

Cooper, R. G., \& Kleinschmidt, E. J. (1996). Winning businesses in product development: the critical success factors. Research Technology Management, 39(4), 18-30.

Dholakia, U. M., Bagozzi, R. P., \& Pearo, L. K. (2004). A social influence model of consumer participation in network-and small-group-based virtual communities. International Journal of Research in Marketing, 21, 241-263. http://dx.doi.org/10.1016/j.ijresmar.2003.12.004

Duncan, T., \& Moriarty, S. (1998). A communication-based marketing model for managing relationships. Journal of Marketing, 62(2), 1-13. http://dx.doi.org/10.2307/1252157

Fournier, S. (1998). Consumers and their brands: developing relationship theory in consumer research. Journal of Consumer Research, 24(4), 343-353. http://dx.doi.org/10.1086/209515

Fournier, S. M., Sele, K., \& Schögel, M. (2005). The paradox of brand community management. Thexis der Universitaet St. Gallen, 22(3), 16-20.

Franke, N., \& Shah, S. K. (2003). How communities support innovative activities: An exploration of assistance and sharing among end-users. Research Policy, 32, 157-178. http://dx.doi.org/10.1016/S0048-7333(02)00006-9

Füller, J., Matzler, K., \& Hoppe, M. (2008). Brand community members as a source of Innovation. Journal of Product Innovation Management, 25, 608-619. http://dx.doi.org/10.1111/j.1540-5885.2008.00325.x

Jin, X. L., Cheung, C. M. K., Lee, M. K. O., \& Chen, H. P. (2009). How to keep members using the information in a computer-supported social network. Computers in Human Behavior, 25, 1172-1181. http://dx.doi.org/10.1016/j.chb.2009.04.008

Kapferer, J. N. (1997). Strategic Brand Management: Creating and Sustaining Brand Equity long term (2nd ed.). London.

Keller, K. L. (1993). Conceptualizing, measuring, and managing customer-based brand equity. The Journal of Marketing, 1-22. http://dx.doi.org/10.2307/1252054

Keller, K. L. (2001). Building customer-based brand equity: a blueprint for creating strong brands (pp. 68-72). Marketing Science Institute.

Keller, K. L. (2003). Strategic Brand Management: Building, Measuring, and Managing Brand Equity (2nd ed.). Prentice-Hall, Upper Saddle River, NJ.

Kim, J. W., Choi, J., Qualls, W., \& Han, K. (2008). It takes a marketplace community to raise brand commitment: the role of online communities. Journal of Marketing Management, 24(3-4), 409-431. http://dx.doi.org/10.1362/026725708X306167

Kotler, P., \& Armstrong, G. (2005). Principles of Marketing (9th ed.). Englewood Cliffs, NJ: Prentice Hall.

Kozinets, R. (1999). E-Tribalized Marketing? The Strategic Implications of Virtual Communities of $\begin{array}{lllll}\text { Consumption. } & \text { European } & \text { Management }\end{array}$ http://dx.doi.org/10.1016/S0263-2373(99)00004-3

Kozinets, R. V. (2002). The field behind the screen: using netnography for marketing research in online communities. Journal of Marketing Research, 39(1), 61-72. http://dx.doi.org/10.1509/jmkr.39.1.61.18935

Kozinets, R., De Valck, K., Wojinicki, A. C., \& Wilner, S. (2010). Networked narratives: Understanding word-of-mouth marketing in online communities. Journal of Marketing, 74, 71-89. http://dx.doi.org/10.1509/jmkg.74.2.71

Laroche, M., Habibi, M. R., Richard, M. O., \& Sankaranarayanan, R. (2012). The effects of social media based brand communities on brand community markers, value creation practices, brand trust and brand loyalty. Computers in Human Behavior, 28(5), 1755-1767. http://dx.doi.org/10.1016/j.chb.2012.04.016

Li, W. (2011, May). How virtual brand community influences on consumer-based brand equity. In E-Business and E-Government (ICEE), 2011 International Conference on (pp. 1-4). IEEE.

Lipinski, J., Walsh, M. F., \& Crothers, L. M. (2011). Brand communities: influencing organisations' identities and their perception of the business environment. International Journal of Business Environment, 4(4), 363-377. http://dx.doi.org/10.1504/IJBE.2011.043649

Manchanda, P., Packard, G., \& Pattabhiramaiah, A. (2012). Social Dollars: The Economic Impact of Customer 
Participation in a Firm-sponsored Online Community. MSI Report No. 11-115.

Matzler, K., Pichler, E., Füller, J., \& Mooradian, T. A. (2011). Personality, person-brand fit, and brand community: An investigation of individuals, brands, and brand communities. Journal of Marketing Management, 27(9-10), 874-890. http://dx.doi.org/10.1080/0267257X.2010.543634

McAlexander, J. H., Schouten, W. John., \& Koening, F. H. (2002). Building brand community. Journal of Marketing, 66, 38-54. http://dx.doi.org/10.1509/jmkg.66.1.38.18451

Moorman, C., Gerald, Z., \& Deshpande, R. (1992). Relationships between Providers and Users of Marketing Research: The Dynamics of Trust within and Between Organizations. Journal of Marketing Research, 29(3), 314-329. http://dx.doi.org/10.2307/3172742

Morgan, R., \& Hunt, S. (1994). The commitment-trust theory of relationship marketing. Journal of Marketing, 58(3), 20-38. http://dx.doi.org/10.2307/1252308

Muniz Jr, A. M., \& O'guinn, T. C. (2001). Brand community. Journal of Consumer Research, 27(4), 412-432. http://dx.doi.org/10.1086/319618

Muniz, A., \& Schau, H. J. (2005). Religiosity in the abandoned Apple Newton brand community. Journal of Consumer Research, 31, 737-747. http://dx.doi.org/10.1086/426607

Nambisan, S., \& Baron, R. A. (2009). Virtual customer environments: Testing a model of voluntary participation in value co-creation activities. Journal of Product Innovation Management, 26(4), 388-406. http://dx.doi.org/10.1111/j.1540-5885.2009.00667.x

Ouwersloot, H., \& Odekerken-Schröder, G. (2008). Who's who in brand communities-and why? European Journal of Marketing, 42(5/6), 571-585. http://dx.doi.org/10.1108/03090560810862516

Porter, M. E., \& Kramer, M. R. (2011). Creating shared value. Harvard business review, 89(1/2), 62-77.

Reid, M. (2005). Performance Auditing of Integrated Marketing Communication (IMC) Actions and Outcomes. Journal of Advertising, 34, 441-454. http://dx.doi.org/10.1080/00913367.2005.10639208

Ridings, C. M., Gefen, D., \& Arinze, B. (2002). Some antecedents and effects of trust in virtual communities. The Journal of Strategic Information Systems, 11(3), 271-295. http://dx.doi.org/10.1016/S0963-8687(02)00021-5

Schau, H. J., Muñiz, A. M. Jr., Arnould, E. J. (2009). How brand community practices create value, Journal of Marketing, 73(5), 30-51. http://dx.doi.org/10.1509/jmkg.73.5.30

Schembri, S. (2008). Reframing brand experience: the experiential meaning of Harley-Davidson. Journal of Business Research, 62(12), 1299-1310. http://dx.doi.org/10.1016/j.jbusres.2008.11.004

Sicilia, M., \& Palazon, M. (2008). Brand communities on the internet: A case study of Coca-Cola's Spanish virtual community. Corporate Communications: An Inter-national Journal, 13(3), 255-270. http://dx.doi.org/10.1108/13563280810893643

Spaulding, T. J. (2010). How can virtual communities create value for business? Electronic Commerce Research and Applications, 9(1), 38-49. http://dx.doi.org/10.1016/j.elerap.2009.07.004

Stokburger-Sauer, N. (2010). Brand community: drivers and outcomes, Psychology and Marketing, 27(4), 347-368. http://dx.doi.org/10.1002/mar.20335

Tajfel, H., \& Turner, J. C. (1985). The social identity theory of intergroup behavior. In S. Worchel \& W. G. Austin (Eds.), Psychology of intergroup relations (pp. 7-24). Chicago: Nelson-Hall.

Thompson, S. A., \& Sinha, R. K. (2008). Brand communities and new product adoption: the influence and limits of oppositional loyalty. Journal of Marketing, 72(6), 65-80. http://dx.doi.org/10.1016/j.jbusres.2011.03.011

Tsai, H. T., Huang, H. C., \& Chiu, Y. L. (2012). Brand community participation in Taiwan: Examining the roles of individual-, group-, and relationship-level antecedents. Journal of Business Research, 65(5), 676-684. http://dx.doi.org/10.1016/j.jbusres.2011.03.011

Wang, Y. C., \& Fesenmaier, D. R. (2004). Modeling participation in an online travel community. Journal of Travel Research, 42(3), 261-270. http://dx.doi.org/10.1177/0047287503258824

Wirtz, J., Den Ambtman, A., Bloemer, J., Horváth, C., Ramaseshan, B., Van De Klundert, J., \& Kandampully, J. (2013). Managing brands and customer engagement in online brand communities. Journal of Service Management, 24(3), 223-244. http://dx.doi.org/10.1108/09564231311326978 
Woisetschläger, D. M., Hartleb, V., \& Blut, M. (2008). How to Make Brand Communities Work: Antecedents and Consequences of Consumer Participation. Journal of Relationship Marketing, 7(3), $237-256$. http://dx.doi.org/10.1080/15332660802409605

Yen, H. R., Hsu, S. H. Y., \& Huang, C. Y. (2011). Good soldiers on the web: Under-standing the drivers of participation in online communities of consumption. International Journal of Electronic Commerce, 15(4), 89-120. http://dx.doi.org/10.2753/JEC1086-4415150403

Yoo, B. (2009). Cross-national invariance of the effect of personal collectivistic orientation on brand loyalty and equity: The United States versus South Korean consumers. Asia Pacific Journal of Marketing and Logistics, 21(1), 41-57. http://dx.doi.org/10.1108/13555850910926236

\section{Copyrights}

Copyright for this article is retained by the author(s), with first publication rights granted to the journal.

This is an open-access article distributed under the terms and conditions of the Creative Commons Attribution license (http://creativecommons.org/licenses/by/3.0/). 